\title{
AOR
}

Selected Papers of \#AolR2021:

The 22nd Annual Conference of the

Association of Internet Researchers

Virtual Event / 13-16 Oct 2021

\section{PRODUCING THE ‘PROBLEM’ OF PARENTAL OVERSHARE}

\author{
Priya C. Kumar \\ Pennsylvania State University, College of Information Sciences and Technology
}

\section{Introduction: Critically Examining Overshare}

With the rise of social media, the term overshare has become shorthand for concerns about people disclosing seemingly excessive amounts of information. Accusations of oversharing typically target information about "sex and romance, intimate relationships, [and] parenthood and reproduction" (Hoffmann, 2009, p. 71). Parents are attuned to concerns about oversharing on social media (Ammari et al., 2015; Kumar \& Schoenebeck, 2015). Hoffmann (2009) argues that the term overshare does not simply describe an action; it reinforces problematic boundaries that marginalize women especially. I extend this line of thinking by examining how social media discourse actively produces overshare and then instructs parents, particularly mothers, to selfcensor in the name of satisfying their social media audience. I focus on STFU, Parents, a once-popular blog dedicated to "mock[ing] parent overshare on social networking sites" (Koenig, n.d.).

\section{Method: Conducting a Governmentality Analysis of STFU, Parents}

My study of overshare follows the analytical framework of governmentality, a Foucauldian-inspired means of examining how authorities intervene in people's lives. Governmentality traces how expertise, manifesting in people, institutions, and discourses, harnesses ideas and materials to regulate social conduct (Miller \& Rose, 2008). To conduct my analysis, I engaged with STFU, Parents material in dialogue with governmentality literature, a method known as thinking with theory (Jackson \& Mazzei, 2012). I explored the blog's informational pages and press coverage and followed multiple pathways through its posts. I examined the author's list of favorite posts, her annual lists of noteworthy posts, and the blog's most commented posts. I also studied posts in each of the tags created by the author. Beyond the blog, I examined the STFU, Parents book as well as the STFU, Parents' column on the parenting website Mommyish. I circulated between STFU, Parents material and governmentality literature, Suggested Citation (APA): Kumar, P.C. (2021, October). Producing the 'Problem' of Parental Overshare. Paper presented at AolR 2021: The 22nd Annual Conference of the Association of Internet Researchers. Virtual Event: AolR. Retrieved from http://spir.aoir.org. 
concentrating on how discursive and material elements dynamically defined what STFU, Parents was trying to accomplish, where it directed its attention, and how others responded.

\section{Findings: How STFU, Parents Produces the Problem of Overshare}

A Brooklyn woman named Blair Koenig created STFU, Parents in 2009 because "some friends in my Facebook feed were driving me crazy by documenting the minutiae of their lives as new parents" (Koenig, n.d.). She invited people to send her screenshots of parents' social media posts, which she published on the blog with snarky, sometimes acerbic, commentary. In 2011, she began writing the STFU, Parents column on Mommyish, and in 2013 she published an STFU, Parents book. The column and book legitimated Koenig as a type of parenting expert, her authority stemming from the blog's thousands of examples of overshare.

I find that STFU, Parents defines overshare as gross or overly emotional content on social media. Gross content is anything related to waste, fluid, and tissue that come out of the body's orifices, which commonly appears on the blog as photos of children's feces or the processes of birth and afterbirth. Overly emotional content includes gratuitous displays of sentiment, from mawkishness to fury. STFU, Parents argues that emotional posts imply that parents' lives revolve around children and that parents expect special treatment simply for being parents. I contend that STFU, Parents regards overshare as a problem because it confronts people with what feminist theorist Margrit Shildrick (1997) calls "leaky bodies." This includes literal leaks, like the material that bodies expel, and conceptual leaks, like the blurring of parent and child identities, especially when children are very young.

STFU, Parents materializes overshare through the technologies of screenshots and editing software. In governmentality, technologies are the tools, techniques, and devices that authorities use to actualize the process of shaping people's conduct (Miller \& Rose, 2008). To support its claim that parents share too much, STFU, Parents solicits screenshots of social media posts. Most of the content STFU, Parents criticizes comes from Facebook, and since such posts are often not publicly visible, screenshots provide the evidence STFU, Parents needs to justify its accusations of overshare. STFU, Parents edits screenshots to redact people's names and block out faces in photos. Koenig wrote that she does so to minimize risk, though in at least one case, an STFU, Parents reader identified a woman from a screenshot and doxed her. The woman said she received hundreds of angry emails and voice mails, some containing death threats. The use of anonymity enables STFU, Parents to distance itself from the consequences of its actions.

\section{Discussion: Overshare is Information Pulled Out of Context}

STFU, Parents separates information from its context and uses it in a way that the people who originally posted the information likely did not anticipate and may not appreciate. As such, STFU, Parents violates the contextual integrity of information (Nissenbaum, 2010) and then labels that information overshare. It complains about 
being confronted with evidence of leaky bodies, but it was never meant to see the information in the first place.

STFU, Parents portrays itself as simply curating a phenomenon-overshare-that exists in the world. However, I argue that overshare does not pre-exist STFU, Parents; rather, STFU, Parents brings overshare into being. The acts of taking a screenshot, blocking out names and faces, and posting the results on a blog crystalize information that once flowed on a Timeline or News Feed into specimens that STFU, Parents has decided to call overshare. STFU, Parents derides what it calls "sanctimommies" who act self-righteous about their parenting and "mommyjackers" who hijack conversations to discuss their children. This echoes Hoffmann's (2009) finding that overshare discourse primarily castigates women. STFU, Parents shames parents, particularly mothers, for displaying their "leaky bodies" and instructs them to avoid posting such content so as to not irritate their social media audience. Presenting overshare as a problem of individuals not knowing proper social media etiquette enables STFU, Parents to distance itself from its role in constructing the very problem it claims to critique.

\section{References}

Ammari, T., Kumar, P., Lampe, C., \& Schoenebeck, S. (2015). Managing children's online identities: How parents decide what to disclose about their children online. Proceedings of the 33rd Annual ACM Conference on Human Factors in Computing Systems (CHI '15), 1895-1904. https://doi.org/10.1145/2702123.2702325

Hoffmann, A. L. (2009). Oversharing: A critical discourse analysis. University of Wisconsin-Milwaukee.

Jackson, A. Y., \& Mazzei, L. A. (2012). Thinking with theory in qualitative research: Viewing data across multiple perspectives (1st ed.). Routledge.

Koenig, B. (n.d.). About the blog. STFU, Parents. Retrieved August 6, 2017, from http://www.stfuparentsblog.com/about

Kumar, P., \& Schoenebeck, S. (2015). The modern day baby book: Enacting good mothering and stewarding privacy on Facebook. Proceedings of the 18th ACM Conference on Computer Supported Cooperative Work \& Social Computing (CSCW'15), 1302-1312. https://doi.org/10.1145/2675133.2675149

Miller, P., \& Rose, N. S. (2008). Governing the present: Administering economic, social and personal life. Polity Press.

Nissenbaum, H. (2010). Privacy in context: Technology, policy, and the integrity of social life. Stanford University Press.

Shildrick, M. (1997). Leaky bodies and boundaries: Feminism, postmodernism and (bio)ethics. Routledge. 